\title{
PERILAKU AGRESIF PADA SISWA SMP YANG BERMAIN GAME ONLINE
}

\author{
Octa Reni Setiawati ${ }^{1}$, Agin Gunado ${ }^{2}$ \\ 1Program Studi Psikologi FK Universitas Malahayati. Email: ores.survive@gmail.com
}

2Program Studi Kedokteran FK Universitas Malahayat.

\section{ABSTRACT: AGRESIF BEHAVIOR IN MIDDLE SCHOOL STUDENT WHO PLAY ONLINE GAMES}

Introduction:Playing online games has become part of the lifestyle. Increased in online games player is supported by the development of very fast internet, in Indonesia internet user has reached 63 million people from the total population. One of the negative impact of online games is emersion of aggressive behavior by the player, like speaking harshly, slamming or throwing a game device, even hitting players who are next to them.

Purpose: The aim of this study is to describe the aggressive behavior in junior high school students who play online games in Bandar Lampung Year 2019.

Methods: This study was analytic cross sectional with a total sample of 539 students.

Results: This study has found 98 students (18.2\%) with a low level of aggressive behavior, 403 students $(74.8 \%)$ with a moderate level of aggressive behavior, and 38 students (7.1\%) with a high level of aggressive behavior.

Conclusion: Based on the results of the study, the average aggressive behavior in junior high school students who play online games in Bandar Lampung has a moderate level of aggressive behavior.

\section{Keywords: The intensity of playing online games, aggressive behavior, internet}

Latar Belakang: Bermain game online sudah menjadi bagian dari gaya hidup. Meningkatnya player game online didukung oleh perkembangan internet yang sangat cepat, di Indonesia pengguna internet mencapai 63 juta orang dari total jumlah penduduk. Salah satu dampak negative dari fame online adalah munculnya perilaku agresif pada pemain, seperti berkata kasar, membanting atau melempar perangkat game, bahkan memukul pemain yang berada disebelahnya.

Tujuan: Penelitian ini bertujuan untuk mengetahui gambaran perilaku agresif pada Siswa SMP yang bermain gameonlinedi Bandar Lampung Tahun 2019.

Metode Penelitian: Desain penelitian ini adalah analitik cross sectional dengan jumlah total sampel 539 Siswa.

Hasil: Penelitian ini menemukan 98 siswa $(18,2 \%)$ dengan perilaku agresif tingkat rendah, 403 siswa $(74,8 \%)$ dengan perilaku agresif tingkat sedang, serta 38 siswa $(7,1 \%)$ dengan perilaku agresif tingkat tinggi.

Kesimpulan: Berdasarkan hasil penelitian, rata-rata perilaku agresif pada siswa SMP yang bermain game online di Bandar Lampung memiliki perilaku agresif tingkat sedang.

Kata Kunci: Intensitas bermain game online, perilaku agresif, internet

\section{PENDAHULUAN}

Perkembangan ilmu pengetahuan dan teknologi seakan tidak pernah berhenti menghasilkan produk-produk teknologi yang tidak terhitung jumlahnya. Produk teknologi yang beragam tentudimaksudkan untuk memenuhi kebutuhan manusia akan pendidikan, ilmu pengetahuan, kesehatan, atau bahkan hanya sekedar hiburan semata. Salah satu produk teknologi yang setiap waktudigemari dikalangan remaja saat ini adalah video games dan game online, sebagai salah satu produk teknologi yang memiliki manfaat hiburan tertentu saja (Kuss \& Griffiths.2012).

Data statistic dunia 2015 mencatat penguna game online sebanyak 49,1 miliar, berdasarkan penelitian profil pengguna internet dari
143,26 juta pengguna internet di Indonesia terdapat 10,1\% merupakan pengguna game oline (APJI 2017). Berdasarkan umur pada tahun 2016, sebanyak 24,4 juta $(18,4 \%)$ pengguna internet di Indonesia berada pada rentan umur 10-24 tahu dan mengalami pertumbuhan yang signifikan ditahun 2017 dengan penetrasi 75,50\%. Intensitas pengguna internet sebanyak $43,89 \%$ menyatakan menggunakan internet sebanyak 1-3 jam perhari, dan sebnayak $54,13 \%$ menggunakan internet untuk bermain game online (APJI, 2017).

Game online adalah game atau permainan digital yang hanya bisa dimainkan ketika perangkat terhubung dengan jaringan internet memungkinkan penggunanya untuk dapat berhubungan dengan pemain-pemain lain yang mengakses game tersebut di waktu yang sama. 
Hasil penelitian yang sebelumnya pernah dilakukan oleh Mark Griffiths dari Nottingham Trent University (Rini dan Ayu, 2011 dalam Putri dan Wahyuni 2017) dimana mayoritas anakanak yang berusia belasan bermain video game setiap hari. Selain itu, $7 \%$ dari mereka dapat menghabiskan waktu hingga 30 jam per minggu. Berdasarkan penelitian lain, Gentile menyatakan bahwa lebih dari 8\% gamer berusia 818 tahun memperlihatkan tanda kecanduan video game. Dari responden survey, rata-rata mereka menghabiskan waktu bermain game untuk anak laki-laki 16,4 jam dan perempuan 9 jam di setiap minggunya (Gentile,2007 dalam Yani, 2017).

Menurut Griffiths (2012), Mereka menggunakan game online sebagai bentuk koping terhadap permasalahan di dunia nyata, seperti kekerasan dan perilaku agresif verbal. Hal ini menjadi alasan peneliti untukmencari gambaran perilaku agresif pada Siswa SMP yang bermain game online di Bandar Lampung Tahun 2019.

\section{METODE PENELITIAN}

Penelitian ini menggunakan jenis penelitian kuantitatif dan metode penelitian analitik dengan pendekatan studi potong lintang cross sectional, pada penelitian ini yang ingin di ketahui adalah gambaranperilaku agresif pada siswa SMP yang bermain game online di Bandar Lampung tahun 2019.

Populasi merupakan keseluruhan dari unit analisis sesuai dengan informasi yang diinginkan, sedangkan sampel adalah sebagian populasi yang terpilih dan mewakili populasi tersebut (Yusuf, 2016). Pada penelitian ini peneliti mengambil sampel siswa SMP pengguna game online yang ada dilingkungan Bandar Lampung tahun 2019 menggunakan metode cluster randomsampling, dengan populasi 21.214 Siswa laki-laki terbagi dalam 113 SMP, didapatkan sampel minimal sebanyak 488 Siswa berdasarkan rumus Issac dan Michael.

\section{HASIL PENELITIAN}

Berdasarkan penelitian yang dilakukan dengan menyebarkan kuisioner intensitas bermain game onlinedan perilaku agresif padasiswa SMP di Bandar Lampung pada bulan Januari 2019 Februari 2019 dengan jumlah 539 responden dari 19 sekolah di setiap kecamatan yang ada di bandar Lampung, didapatkan hasil sebagai berikut:

Tabel 1. Distribusi Frekuensi Intensitas Bermain Game Online pada Siswa SMP di Bandar Lampung Tahun 2019.

\begin{tabular}{ccc}
\hline Intensitas Bermain Game Online & Jumlah & Presentase \\
\hline Rendah & 100 & $18,6 \%$ \\
Sedang & 358 & $66,4 \%$ \\
Tinggi & 81 & $15,0 \%$ \\
\hline Total & 539 & 100 \\
\hline
\end{tabular}

Berdasarkan tabel 1 diatas, hasil penelitian pada siswa SMP di Bandar Lampung Tahun 2019, di dapatkan 100 siswa (18,6\%) dengan intensitas bermain game online tingkat rendah, 358 siswa $(66,4 \%)$ dengan intensitas bermain game onlinetingkat sedang, serta 81 siswa $(15,0 \%)$ dengan intensitas bermain game online tingkat tinggi.

Tabel 2.Distribusi Frekuensi Perilaku Agresif Bermain Game Online pada Siswa SMP di Bandar Lampung Tahun 2019.

\begin{tabular}{ccc}
\hline Perilaku Agresif & Jumlah & Presentase \\
\hline Rendah & 98 & $18,2 \%$ \\
Sedang & 403 & $74,8 \%$ \\
Tinggi & 38 & $7,1 \%$ \\
\hline Total & 539 & $100 \%$
\end{tabular}

Berdasarkan Tabel 2 diatas, hasil penelitian pada Siswa SMP di Bandar Lampung Tahun 2019, di dapatkan 98 siswa $(18,2 \%)$ dengan perilaku agresif dengan tingkat rendah, 403 siswa $(74,8 \%)$ dengan perilaku agresif tingkat sedang, serta 38 siswa $(7,1 \%)$ denganperilaku agresif tingkat tinggi. Dengan hasil penelitian tersebut, disebutkan bahwa rata-rata siswa SMP di Bandar Lampung tahun 2019memiliki perilaku agresif tingkat sedang.

Octa Reni Stiawati ${ }^{1}$.Program Studi Psikologi FK Universitas Malahayati, Bandar Lampung. Email: ores.survive@gmail.com

Agin Gunado2. Program Studi Pendidikn Dokter FK Universitas Malahayati, Bandar Lampung 
Berdasarkan hasil uji statistik Spearman pada intensitas bermain game online dan perilaku agresif diperoleh nilai $P$ value $=0,000(P<0,05)$, artinya terdapat "hubungan bermakna antara perilaku agresif dengan intensitas bermain game online pada siswa SMP di Bandar Lampung Tahun 2019 ". Nilai korelasi $r=0,539$, artinya kekuatan korelasi penelitian ini memiliki keeratan kuat. Hal ini sesuai dengan teori yang mengatakan bahwa semakin tinggi intensitas bermain game online pada remaja, akan memiliki perilaku agresif yang tinggi.

Tabel 3. distribusi frekuensi jenis game online yang menyebabkan perilaku perilaku agresif pada Siswa SMP di Bandar Lampung.

\begin{tabular}{ccccc}
\hline Jenis Game & \multicolumn{3}{c}{ Tingkat Agresif } & Total Siswa \\
\cline { 2 - 4 } & Rendah & Sedang & Tinggi & \\
\hline Tidak Diketahui & 20 & 3 & 1 & 24 \\
Dota 2 & 3 & 7 & 0 & 10 \\
Free Fire & 8 & 66 & 8 & 82 \\
Hago & 4 & 1 & 0 & 5 \\
Mobile Legends & 38 & 198 & 14 & 250 \\
PUBG Mobile & 24 & 126 & 15 & 165 \\
Ragnarok Mobile & 1 & 1 & 0 & 2 \\
Rules Of Survival & 0 & 1 & 0 & 1 \\
\hline Total & 98 & 403 & 38 & 539 \\
\hline
\end{tabular}

Berdasarkan tabel 3. di atas menunjukan bahwa distribusi frekuensi jenis game online yang paling tinggi menyebabkan perilaku agresif pada Siswa SMP di Bandar Lampung adalah game online Mobile Legends, sedangkan yang paling rendah adalah game online Hago.

\section{DISKUSI}

Berdasarkan hasil penelitian, ditemukan bahwa rata-rata siswa SMP di Bandar Lampung memiliki intensitas bermain game online yang tergolong sedang. Hal tersebut didasari berdasarkan penelitian dari Chaplin (dalam Haqq, 2016), bahwa aspek-aspek intensitas bermain game online berdasarkan frekuensi, lama waktu, perhatian penuh, dan konsentrasi.

Selanjutnya, untuk perilaku agresif ditemukan bahwa rata-rata siswa SMP di Bandar Lampung memiliki perilaku agresif tingkat sedang. Hal ini bisa diartikan bahwa perilaku agresif siswa sebagian besar diatas rata-rata. Kejadian ini dapat berhubungan dengan faktor kekerasan yang berada di tampilan game online terkait. Faktor tersebut didukung oleh pendapat Baron dan Byrne (2005) yang menyatakan bahwa faktorfaktor penyebab munculnya perilaku agresif salah satunya adalah media baik cetak ataupun elektronik yang bisa dilihat, didengar, maupun dibaca salah satunya seperti game.

Lebih lanjut, bentuk perilaku agresif tingkat sedang yang muncul dapat berupa perilaku menyerang suatu objek, menyerang secara verbal atau simbolis, serta melanggar benda hak milik orang lain. Hal ini juga selaras dengan temuan peneliti di salah satu SMP yang berada di Bandar Lampung, beberapa Siswa terlihat bermain game online ketika jam istirahat dan sering mengeluarkan kata-kata kasar seperti "bangsat", "Asu", dan kata-kata tidak layak lainnya yang terucap. Selain itu, beberapa kali Siswa yang kalah bermain game terkait terlihat memukul meja yang berada di depannya bahkan mengejek atau mencemooh teman yang berada di dekatnya. Hal ini sependapat dengan teori Havighrust (dalam Hutomo, 2017) menyatakan bahwa tugas perkembangan remaja adalah mencapai kemandirian emosi. Maka dapat ditarik kesimpulan bahwa kecenderungan agresivitas pada remaja awal adalah perilaku menyakiti orang lain yang dilakukan remaja yang tidak dapat mencapai kemandirian emosi yang baik, secara fisik maupun verbal terhadap individu atau objek lain dan dilakukan semata-mata sebagai pelampiasan keinginan untuk menyakiti dan melukai individu dan objek lain.

Perilaku agresif rendah ditemukan pada siswa SMP di Bandar Lampung Tahun 2019 yang bermain game online dengan jumlah 98 siswa $(18,2 \%)$, artinya Siswa tersebut masih bisa mengontrol emosi dengan hanya sesekali merasa kesal ketika kalah atau tidak tercapainya suatu tujuan dalam game tersebut. Sedangkan perilaku agresif Tinggi, ditemukan sebesar 38

Octa Reni Stiawati ${ }^{1}$.Program Studi Psikologi FK Universitas Malahayati, Bandar Lampung. Email:

ores.survive@gmail.com

Agin Gunado². Program Studi Pendidikn Dokter FK Universitas Malahayati, Bandar Lampung 
siswa $(7,1 \%)$, perilaku agresif ini berupa menyerang secara fisik, mudah meluapkan emosi, emosi sulit untuk dikendalikan, dalam ini peneliti tidak menemukan Siswa yang memperlihatkan perilaku agresif tinggi secara objektif, kemungkinan dikarenakan faktor peraturan masing-masing sekolah yang menekankan terhadap Siswa untuk selalu tertib baik didalam maupun diluar lingkungan Sekolah.

Medinus dan Johnson mengemukakan bahwa agresi adalah perilaku yang bersifat menyerang, dapat berupa serangan fisik, serangan terhadap objek, serangan verbal, dan melakukan pelanggaran terhadap hak milik atau menyerang daerah orang lain. Lebih lanjut Medinus dan Johnson (1997 dalam Wardana, 2014) mengemukakan bahwa agresi adalah serangakaian tindakan atau tingkah lakuyangbermaksud merugikan atau melukai. Agresi walaupun merupakan konsep yang sangat familiar tetapi tidak mudah untuk mendefinisikannya. Agresi dikategorikan sebagai perilaku yang disebabkan oleh terlalu meningkatnya hormon testoteron. Perilaku agresi merupakan salah satu respon yang muncul dari rasa frustasi (Watson, 1984 dalam Febrianti, 2015).

Hasil uji statistik Spearman menunjukkan adanya hubungan bermakna antara perilaku agresif pada siswa SMP yang bermain game online. Nilai korelasi $r=0,539$, artinya kekuatan korelasi penelitian ini memiliki keeratan kuat. Hal ini sesuai dengan teori yang mengatakan bahwa semakin tinggi intensitas bermain game online pada remaja, akan memiliki perilaku agresif yang tinggi.

Hal ini sesuai dengan hasil penelitian oleh Taufan Akbar Haqq (2016) di Malang, diperoleh nilai rxy $=0,556$ dengan $p<0,01$ menunjukkan bahwa ada hubungan positif yang sangat signifikan antara intensitas bermain game online dan perilaku agresif pada remaja awal. Hal ini berarti semakin tinggi skor intensitas bermain game online, maka semakin tinggi pula skor perilaku agresif pada remaja awal. Sebaliknya semakin rendah skor intensitas bermain game online, maka semakin rendah pula skor perilaku agresif pada remaja awal.

Hasil yang diperoleh sesuai dengan teori yang menyatakan bahwa perilaku agresif pada remaja awal dipengaruhi oleh beberapa faktor salah satunya pengaruh media seperti internet. Bandura (dalam Baron dan Byrne, 1994) menyatakan bahwa perilaku agresi merupakan hasildariproses belajar social melalui pengamatan terhadap dunia sosial.
Ada penularan perilaku yang disebabkan seringnya seseorang melihat tayangan perilaku agresi melalui televisi atau membaca surat kabar yang memuat hasil perilaku agresi, seperti pembunuhan, tawuran masal, dan penganiayaan (Fisher dalam Waas, 2015).

Perilaku agresif pada remaja adalah suatu arah tertentu dari kemajuan gerakan atau pikiran untuk berperilaku yang bertujuan menyerang atau melukai orang ataupun objek lain dan dilakukan dengan kesengajaan oleh seseorang yang berusia 12-18 tahun baik secara verbal maupun fisik sehingga akan menyebabkan rasa sakit baik secara fisik maupun psikis bagi individu yang tidak menginginkan timbulnya perilaku tersebut.

Oleh karena itu peneliti menyimpulkan bahwa, perilaku agresif yang muncul pada remaja yang berusia 12-18 tahun terutama Siswa SMP bermain game online dengan perilaku agresif yang memprihatinkan. Seringnya bermain,hinggajenis permainan yang dipilih untuk dimainkan sangat mempengaruhiperilaku agresif yang muncul. Bentuk perilaku agresif yang muncul padagame online mengakibatkan para remaja tersebut melakukan tindakan atauperilaku agresif, seperti membanting keyboard, membanting handphone, saling mengejek,mengeluarkan katakata kasar, hingga memukul teman lain

Lebih lanjut, dalam penelitian ini, peneliti juga menemukan jenis-jenis gameonline yang digunakan oleh siswa SMP, dimana ditemukan bahwa siswa yang bermain Mobile Legends dan PUBG Mobile menunjukkan perilaku agresif paling tinggi dibandingkn siswa yang bermain gameonline lain. Mobile Legends dan PUBG Mobile merupakan salah satu gameonlineyang didalamnya mengandung unsur-unsur kekerasan, seperti memukul karakter lawan, menembak menggunakan senjata, mencabik-cabik menggunakan pedang, dan masih banyak lagi yang dapat membuat remaja awal meniru hal-hal tersebut yang berada didalam konten game terkait. Selain itu, faktor terkenalnya game Mobile Legends dan PUBG Mobile membuat kalangan remaja berbondong-bondong ingin mencoba memainkannya, sehingga membuat player game tersebut ketagihan. Selain itu, faktor sosial sangat berpengaruh, peneliti melakukan wawancara terhadap salah satu siswa SMP di Bandar Lampung yang memainkan game Mobile Legends dan PUBG Mobile menyatakan bahwa dalam kehidupan sehari-hari Siswa tersebut lebih memilih berdiam diri dirumah dan bermain

Octa Reni Stiawati ${ }^{1}$.Program Studi Psikologi FK Universitas Malahayati, Bandar Lampung. Email:

ores.survive@gmail.com

Agin Gunado². Program Studi Pendidikn Dokter FK Universitas Malahayati, Bandar Lampung 
game online sampai larut malam dari pada bermain dengan teman sebayanya diluar rumah, artinya kehidupan sosial Siswa tersebut rendah. Sedangkan menurut peneliti lain seseorang yang mempunyai keterampilan sosialnya rendah, cenderung lebih banyak menggunakan media sosial maupun media game, bahkan hingga ke taraf yang dikatakan kecanduan (Majorsy, Kinasih, Andriani, dan Lisa, 2013)

Tampaknya, media sosial maupun game online menjadi sarana pelarian yang aman untuk memenuhi kebutuhan sosial atau kebutuhan hiburan. Hal ini juga didukung teori Bartle (dalam Bainbridge, 2010:48-49) yang mengatakan salah satu motivasi gamers dalam bermain game online yaitu, bersosialisasi dengan gamer lain (socializers).

\section{SIMPULAN DAN SARAN}

Diketahui bahwa gambaran perilaku agresif pada Siswa SMP di Bandar Lampung yang bermain game online tahun 2019 dapatkan 98 siswa $(18,2 \%)$ dengan perilaku agresif dengan tingkat rendah, 403 siswa $(74,8 \%)$ dengan perilaku agresif tingkat sedang, serta 38 siswa $(7,1 \%)$ dengan perilaku agresif tingkat tinggi. Dengan hasil penelitian tersebut, disebutkan bahwa rata-rata siswa SMP di Bandar Lampung tahun 2019memiliki perilaku agresif tingkat sedang.

Berdasarkan hasil penelitian disarankan untuk pihak sekolah dapat melakukan pengawasan serta edukasi terhadap siswa dan orang tua tentang dampak negatif bermain game online dalam kaitannya dengan memunculkan perilaku agresif.

\section{DAFTAR PUSTAKA}

APJII. (2017). Diunduh dari https://apjii.or.id/. (diakses 18 November 2018).

Baron, R. A., \& Byrne, D. (2005). Social Psychology Tenth Edition. Alih bahasa: Ratna Djuwita.

Febrianti, T., Suprapti, A., \& Sulian, I. (2015). Pengaruh Layanan Konseling Kelompok Terhadap Perilaku Agresif Siswa Kelas VII 1 di SMP Negeri 3 Kota Bengkulu (Doctoral dissertation, Universitas Bengkulu).
Haqq, T. A. (2016). Hubungan antara intensitas bermain game online terhadap agresivitas remaja awal di warnet "A, B dan C" Kecamatan Lowokwaru Kota Malang (Doctoral dissertation, Universitas Islam Negeri Maulana Malik Ibrahim).

Hutomo, M. R., \& Ariati, J. (2017). Kecenderungan Agresivitas Remaja Ditinjau Dari Jenis Kelamin Pada Siswa SMP Di Semarang. Empati, 5(4), 776-779.

Kuss, D. J., \& Griffiths, M. D. (2012). Online gaming addiction in children and adolescents: A review of empirical research.

Majorsy, U., Kinasih, A. D., Andriani, I., \& Lisa, W. (2013). Hubungan antara Keterampilan Sosial dan Kecanduan Situs Jejaring Sosial pada masa Dewasa Awal. Prosiding PESAT, 5.

Putri, I. C., \& Wahyuni, M. (2017). Hubungan antara Durasi Bermain Video Game dengan Prestasi Belajar pada Siswa Kelas IV \& V SDN 007 Samarinda.

Waas, P. M. (2015). Hubungan antara Kecanduan Bermain Game Online Jenis Massively Multiplayer Online First Person Shooter dengan Perilaku Agresif pada Mahasiswa Universitas Kristen Satya Wacana (Doctoral dissertation, Program Studi Psikologi FPSI-UKSW).

Wardana, S. (2014). Hubungan Forgiveness dengan Perilaku Agresi pada Remaja (Studi Pada Sekolah Menengah Kejuruan Kansai Pekanbaru) (Doctoral dissertation, Universitas Islam Negeri Sultan Sarif Kasim Riau).

Yani, J.A. (2017). Hubungan antara Kebiasaan Bermain Video Game dengan Interaksi Sosial pada Anak di Sekolah Dasar Muhammadiyah Bantul Yogyakarta.

Yusuf, A. M. (2016). Metode penelitian kuantitatif, kualitatif \& penelitian gabungan. Prenada Media.

Octa Reni Stiawati ${ }^{1}$.Program Studi Psikologi FK Universitas Malahayati, Bandar Lampung. Email: ores.survive@gmail.com Agin Gunado². Program Studi Pendidikn Dokter FK Universitas Malahayati, Bandar Lampung 